\title{
Petrogenesis of metamafic rocks at Ndogbesol area, SW Cameroon: evidence of oceanic remnants in the Central African Fold Belt
}

\author{
M. NZEPANG TANKWA ${ }^{1,2^{*}}, \mathrm{~S} . \mathrm{GANNO}^{2}$, O. A.
} OKUNLOLA $^{1}$, J.P. NZENTI ${ }^{2}$

${ }^{1}$ Department of Geology, Pan-African University of Life and Earth Sciences Institute, University of Ibadan, Ibadan, Nigeria (*presenting author: marvinesean@yahoo.fr)

${ }^{2}$ Department of Earth Sciences, University of Yaoundé I, P.O. Box 812, Yaoundé, Cameroon

Ndogbesol area lies within the south most limit of the Yaoundé group (YG). The YG corresponds to a metasedimentary unit of the Central African Fold Belt (CAFB), thrusting southward onto the Congo craton in Cameroon. Investigations of four drillholes from Ndogbesol area revealed the occurrence of metamafic rocks consisting of pyroxenite and epidote amphibolite, interbedded with metasediments (muscovite biotite garnet gneiss). The rock units show sharp and conformable contacts. In this study ICPMS whole rock geochemical data of these metamafic rocks were used to constrain the petrogenesis and tectonic setting of the area. The Metamafic rocks have basalt to alkali basalt compositions with calc-alkaline affinity. They show chondrite normalized REE patterns similar to EMORB, with LREE enrichment over HREE and slight negative $\mathrm{Eu}$ anomalies (0.80-0.95). Primitive mantle normalized multielements plots show LILE enrichment over HFSE, with peaks of $\mathrm{Ba}$ and Th, troughs in $\mathrm{Sr}$ and slight negative to no $\mathrm{Nb}$ anomaly. $\mathrm{Th} / \mathrm{Nb}$ (0.12-0.17) and $\mathrm{La} / \mathrm{Nb}(0.98-1.28)$ ratios suggest absence of crustal assimilation. The $\mathrm{Dy} / \mathrm{Yb}$ and $(\mathrm{La} / \mathrm{Yb}) \mathrm{CN}$ ratios denote absence of garnet fractionation and indicate that the rocks originated from low degree partial melting $(\sim 3 \%)$ of a spinelperidotite mantle source. Ti/V ratios (38.87-44.02) present MORB compositions, consistent with their REE patterns. Furthermore, in the $\mathrm{Nb} / \mathrm{Yb}-\mathrm{Th} / \mathrm{Yb}$ diagram, overall samples are clustered around the EMORB field. Therefore, it is suggested that the metamafic rocks occurring at the margins of the YG in Cameroon are evidence of oceanic remnants in the crustal evolution of the CAFB similar to that reported in the Neoproterozoic Sergipano belt in NE Brazil. 